\title{
MISCELLANEOUS.
}

\section{Occurrence of Rhinolophus Hipposideros in Ireland.}

\section{To the Editors of the Annals of Natural History.}

Dublin, April 14, 1859.

Gentlemen,-Perhaps it may be of interest to state that the Lesser Horse-shoe Bat (Rhinolophus Hipposideros) has been met with in some numbers in a cave near the town of Ennis, county of Clare, last month, by Mr. F. J. Foot. The cave is called Balliallia, and is one of the numerous hollows that occur in the Carboniferous limestone of that county and of Kerry, \&c. The paper being the first record of its discovery in Ireland was read by Professor Kinahan at a meeting of the Dublin Natural History Society, held on Friday the 1st of April.

So few of the Bat tribe have hitherto been recorded in this country, compared with those occurring in England, that a notice of it may be interesting. Professor Bell has confirmed the correctness of the species.

I am, Gentlemen, your most obedient Servant,

F.

\section{Saxicava rugosa a Byssus-spinner. By David Robertson.}

To the Editors of the Annals of Natural History.

Glasgow, June 14, 1859.

Gentlemen,-I beg to offer the following observations in confirmation of Mr. West's paper in the last Number of the 'Annals,' as to Saxicava migosa being a byssus-spinner.

Last year, in the month of March, I had a Saxicava rugosa (length of shell $1 \frac{2}{16}$ inch, breadth $\frac{9}{16}$ ths of an inch), which span freely, but in this instance did not use the byssus to secure a permanent attachment to any particular site and prevent a change of position while the continuity of the cord held good, as is the case with the common Mussel, but seemingly as a cable to fix and hold fast by in its wanderings, with a power to give it out at pleasure.

On the 16th of March the animal was placed in a six-ounce widemouthed vial. On the 17 th it had attached two filaments to the glass. On the 22 nd it had shifted half an inch forward, and given out as much cable as allowed the desired advance. At this stage it fixed the cord to the glass, close by the shell, by two other short filaments. On the 28th it moved still further forward, giving out more cable, and again fixing it by more filaments, as before.

At that time, not being aware that the spinning-properties of Saxicava rugosa were unknown to conchologists, and having no other object in view than securing the byssus for the microscope and the shell for my cabinet, my observations terminated.

I am, Gentlemen, your obedient Servant,

David Robertson. 


\section{$2 \mathrm{BHL}$ Biodiversity Heritage Library}

1859. "Occurrence of Rhinolophus Hipposideros in Ireland." The Annals and magazine of natural history; zoology, botany, and geology 4, 80-80.

View This Item Online: https://www.biodiversitylibrary.org/item/19633

Permalink: https://www.biodiversitylibrary.org/partpdf/31435

\section{Holding Institution}

Natural History Museum Library, London

\section{Sponsored by}

Natural History Museum Library, London

\section{Copyright \& Reuse}

Copyright Status: Public domain. The BHL considers that this work is no longer under copyright protection.

This document was created from content at the Biodiversity Heritage Library, the world's largest open access digital library for biodiversity literature and archives. Visit BHL at https://www.biodiversitylibrary.org. 